\title{
FAKTOR-FAKTOR YANG MEMPENGARUHI PERMINTAAN BERAS ORGANIK
} DI YOGYAKARTA

\author{
Siwitri Munambar \\ Politeknik Pembangunan Pertanian Yogyakarta-Magelang \\ J1. Kusumanegara No.2, Yogyakarta, 55167 \\ Email :siwiyk@gmail.com
}

\section{ABSTRACT}

Quality food is one of the challenges that must be realized by the government. One of the quality foods is organic rice. Organic rice in addition to ensuring environmental sustainability is positive for consumer health. This research was conducted to determine the factors that influence consumer purchases of organic rice. The analytical method used in this research is factor analysis. Based on the results of data processing with explanatory factor analysis techniques, two factors are formed which influence consumer demand for organic rice in Yogyakarta. Factor I is product and factor II is consumer social.

Keyword : Consumer, Organic rice

\section{PENDAHULUAN}

Masyarakat Indonesia adalah masyarakat pengkonsumsi beras. Meskipun banyak sumber pangan lain yang dapat dijadikan untuk memenuhi kebutuhan karbohidrat, tapi masyarakat Indonesia masih menganggap bahwa beras masih sebagai bahan pangan pokok yang belum tergantikan, sehingga masyarakat menganggap mengkonsumsi nasi adalah sangat penting. Lebih dari 95\% penduduk Indonesia mengkonsumsi beras. Ini tidak lain karena beras merupakan salah satu bahan makanan pokok, sehingga beras menjadi salah satu komoditas yang mempunyai peranan penting baik dari sisi produsen, konsumen, pemerintah maupun masyarakat dan lingkungan secara umum (BPS, 2015).

Pemenuhan kebutuhan beras yang tinggi di Indonesia menjadi tanggung jawab dua pihak utama yaitu produsen dan pihak yang terlibat dalam pemasarannya. Produsen sebagai penghasil beras diharapkan dapat meningkatkan produksi beras dan pihak yang terlibat dalam pemasaran beras diharapkan mampu untuk mendistribusikan beras secara efektif dan efisien. Sinergi antara kedua pihak tersebut memiliki tujuan utama untuk memenuhi keinginan konsumen yang terus berkembang menuntut peningkatan dalam tiga hal yaitu kualitas, kuantitas, dan kontinuitas dari ketersediaan beras agar keinginan konsumen tersebut dapat terus terpenuhi. Keinginan konsumen yang terus meningkat ini bisa menjadi sebuah peluang baik bagi kelangsungan industri beras di Indonesia mengingat permintaan yang tinggi. Sulistyana (2014), dalam penelitiannya menyatakan bahwa konsumsi beras organik secara positif dipengaruhi oleh harga beras non organik, harga mie instan, faktor kesehatan dan dipengaruhi secara negatife oleh harga tempe dan harga tahu. Sedangkan Tisnawati (2015), menyatakan bahwa permintaan beras organik di kota Denpasar dipengaruhi oleh dua faktor, yaitu faktor sosial konsumen dan faktor produk dan manfaatnya.

Seiring dengan kemajuan di bidang 
ilmu dan teknologi, pengetahuan dan kesadaran masyarakat akan pentingnya untuk menjaga lingkungan dan menjaga kesehatan semakin meningkat. Salah satu hal yang bisa dilakukan untuk itu adalah dengan mengkonsumsi pangan yang sehat, yaitu dengan mengkonsumsi beras organik. Beras organik merupakan salah satu beras yang didapatkan dari penggilingan padi yang dibudidayakan secara organik. Beras organik dirasa mampu memberikan manfaat yang baik bagi kesehatan konsumen. Namun di wilayah Yogyakarta konsumsi terhadap beras organik masih tergolong rendah, jika dibandingkan dengan beras non organik. Untuk itu penelitian ini dilakukan dengan tujuan untuk mengetahui faktor-faktor yang mempengaruhi permintaan beras organik di Wilayah Yogyakarta.

\section{BAHAN DAN METODE}

\section{Tempat dan Waktu Penelitian}

Penelitian dilakukan di Yogyakarta, dengan responden adalah konsumen yang telah membeli beras organik.

\section{Pengumpulan Data}

Teknik penentuan sampel yang digunakan dalam penelitian ini adalah purposive sampling. Jogiyanto (2005), pengambilan sampel secara purposive sampling dilakukan dengan mengambil sampel dari populasi berdasarkan suatu kriteria tertentu. Kriteria yang digunakan dalam penelitian ini adalah dimana penentuan responden dilakukan secara sengaja terhadap konsumen yang melakukan pembelian beras organik. Pengumpulan data dilakukan dengan menggunakan kuesioner terstruktur (structured questionnaire). Data yang digunakan adalah data primer, dan data sekunder sebagai data pendukung.

\section{HASIL DAN PEMBAHASAN}

Karakteristik Responden Berdasarkan Jumlah Beras Organik Yang Dikonsumsi

Banyaknya beras organik yang dibeli dan dikonsumsi oleh responden dalam penelitian ini sangatlah bervariasi. Hal ini tergantung dari jumlah keluarga, tingkat pendapatan keluarga, harga beras organik, kemudahan untuk mendapatkan beras organik, sampai dengan riwayat kesehatan yang ada dalam keluarga. Rerata konsumsi beras organik dari responden penelitian adalah 4,12 kilogram perbulan.

Tabel 1. Rerata Konsumsi Beras Organik (kilogram) per Bulan

\begin{tabular}{lr}
\hline Keterangan & Jumlah (kilogram) \\
\hline Maksimum & 1 \\
Minimum & 15 \\
Rerata & 4.12 \\
\hline Sumber : Analisis Data primer, 2019
\end{tabular}

Merujuk pada tabel 1.dapat diketahui bahwa konsumsi beras organik selama satu bulan adalah sebesar 1 kilogram, dan konsumsi tertinggi adalah 15 kilogram perbulan. $70 \%$ Responden atau sebanyak 24 orang masih mengkonsumsi beras organik dibawah 5 kilogram per bulan. Sisanya 11,7\% antara 5-10 kilogram per bulan dan dan 17,6 $\%$ responden mengkonsumsi beras organik di atas 10 kilogram perbulan. Beras organik yang dikonsumsi oleh responden terdiri dari beras merah, beras hitam ataupun beras putih.

Sebagian besar responden, mengkonsumsi beras organik masih belum rutin. Perbadningan bayaknya beras organik yang dibeli dan dikonsumsi oleh responden 
masih sangat besar. Responden dalam satu bulan rata-rata membeli dan mengkonsumsi beras biasa (unorganik) sebesar 19,4 kilogram. Jadi perbandingan antara beras organik dan unorganik yang dikonsumsi oleh responden adalah 5:1.

Masih rendahnya kesadaran untuk mengkonsumsi beras organik, disebabkan oleh beberapa faktor antara lain adalah harga beras organik yang masih relatif lebih tinggi jika dibandingkan dengan yang unorganik. Ketersediaan dan kemudahan untuk mendapatkan, serta kebiasaan dalam mengkonsumsi beras organik yang belum terbentuk di masyarakat.

Karakteristik Responden menurut umur dan jenis Kelamin Responden

Tabel 2. Identitas Responden Menurut Umur Konsumen

\begin{tabular}{lrrrrr}
\hline \multirow{2}{*}{ Jenis Kelamin } & \multicolumn{5}{c}{ Umur (tahun) } \\
\cline { 2 - 6 } & $<31$ & $31-40$ & $41-50$ & $51-60$ & $>61$ \\
\hline Laki-Laki & 1 & 3 & 21 & 4 & \\
Perempuan & 1 & 4 & 24 & 4 & 1 \\
\hline Jumlah & 1 & 3 & & 1 \\
\hline Sumber : Analisis Data Primer, 2019 & & &
\end{tabular}

Berdasarkan Tabel 2 dapat dilihat bahwa dari 34 responden konsumen beras yang terdapat di Daerah Istimewa Yogyakarta $14,7 \%$ berjenis kelamin laki-laki, dan sisanya $85,3 \%$ berjenis kelamin perempuan. Sebagian besar konsumen yang membeli beras organik terdapat di rentang usia 41-50 tahun sebanyak 24 responden dengan persentase terbesar berjumlah 70,1\%, dengan jumlah responden berjenis kelamin laki-laki berjumlah 3 orang dan responden berjenis kelamin perempuan berjumlah 20 jiwa.

\section{Karakteristik Responden menurut Pekerjaan Responden}

Konsumen beras organik memiliki pekerjaan yang beragam. Berikut adalah perbandingan jumlah pekerjaan konsumen beras yang ada di Yogyakarta.

Tabel 3. Pekerjaan Konsumen Beras Organik diwilayah Yogyakarta

\begin{tabular}{lrr}
\hline Pekerjaan & Jumlah & Persentase (\%) \\
\hline IRT & 19 & 55,9 \\
Swasta & 4 & 11,8 \\
Wiraswasta & 4 & 11,8 \\
PNS & 6 & 17,6 \\
Lainnya & 1 & 2,9 \\
\hline Total & 34 & $100 \%$ \\
\hline Sumber : Analisis Data Primer, 2019 & &
\end{tabular}

Berdasarkan tabel 3 dapat dilihat bahwa pekerjaan responden terbanyak adalah IRT dengan persentase sebesar 55,9 $\%$. Diikutin dengan pekerjaan responden yaitu pegawai swasta, wiraswasta, dan PNS masing masing berjumlah $11,8 \%, 11,8 \%$ dan $17,6 \%$. Pekerjaan yang paling sedikit dari responden beras adalah di kategori lainnya, 2,9\%. Dapat disimpulkan bahwa pekerjaan responden pada umumnya adalah seorang IRT yang terbiasa untuk membeli kebutuhkan konsumsi beras untuk keluarga.

\section{Karakteristik Responden Menurut Tingkat Pendidikan Responden}

Tingkat pendidikan dapat mempengaruhi pilihan terhadap suatu keputusan yang diambil oleh konsumen. Semakin tinggi tingkat pendidikan konsumen, maka akan semain tinggi pula pengetahuan dan wawasannya terhadap preferensi produk yang akan dibeli. Semakin tinggi pengetahuan dan wawasan konsumen, maka akan semakin baik keputusan yang diambil konsumen tersebut dalam membeli beras organik. 
Tabel 4. Kakarteristik Responden Menurut Tingkat Pendidikan

\begin{tabular}{lrr}
\hline Tingkat Pendidikan & Jumlah (jiwa) & Persentase (\%) \\
\hline Tidak Sekolah & 0 & 0 \\
SD & 3 & 8,8 \\
SMP & 3 & 8,8 \\
SMA & 10 & 29,5 \\
PT & 18 & 52,9 \\
\hline Jumlah & 34 & 100 \\
\hline Sumber : Analisis Data Primer, 2019 & &
\end{tabular}

Berdasarkan Tabel 4.dapat dilihat bahwa 53,9\% responden memiliki tingkat pendidikan di jenjang Perguruan Tinggi. Selebihnya29,5\% responden berpendidikan SMA, sisanya bependidiakn SD dan SMP, masing-masing sebesar 8,8\%. Dengan tingkat pendidikan responden yang di atas 50\% mengenyam pendidikan minimal SMA diharapkan responden memahami tentang beras organik yang dikonsumsi.

\section{Analisis faktor yang mempengaruhi konsumsi beras organik}

Analisis faktor digunakan untuk mengetahui faktor-faktor apa sajakah yang mempengaruhi konsumen dalam melakukan konsumsi beras organik. Variabel yang diamati meliputi variabel manfaat, kemurnian, rasa, aroma, kemasan, kandungan gizi, gaya hidup. Untuk melihat apakah sebuah analisis faktor layak atau tidaknya untuk dilakukan, perlu melakukan Uji KaiserMeyer-Olkin (KMO) measure of adequacy dan Bartlett Test of spericity terlebih dahulu. Uji KMO mempertanyakan kelayakan (appropriateness) analisis faktor. Analisis faktor layak dilakukan jika nilai KMO lebih dari 0,5 (Simamora, 2005). Hasil uji KMO disajikan dalam tabel 5 berikut ini:
Tabel 5. Hasil Uji KMO dan Bartlett Test

\begin{tabular}{lrr}
\hline \multicolumn{3}{c}{ KMO and Bartlett's Test } \\
\hline Kaiser-Meyer-Olkin Measure of Sampling \\
Adequacy. \\
Bartlett's Test of & .786 \\
Sphericity & df & \\
& Sig. & .000 \\
\hline \multicolumn{3}{l}{ Sumber : Analisis data primer, 2019}
\end{tabular}

Berdasarkan hasil Uji KMO dan Bartlett Test pada tabel 5 di atas diketahui bahwa nilai KMO adalah 0,786, sehingga analisis faktor layak untuk dilakukan pada analisis data selanjutnya.

Peranan masing-masing variabel dari berbagai macam variabel yang dikaji (X1 sampai dengan X7) terhadap faktor yang dibentuk dapat dijelaskan dengan mengamati nilai pada hasil communalities pada tabel berikut ini:

Tabel 6. Nilai Communalities

\begin{tabular}{|c|c|c|}
\hline \multicolumn{3}{|c|}{ Communalities } \\
\hline & Initial & Extraction \\
\hline $\mathrm{X} 1$ & 1.000 & .815 \\
\hline $\mathrm{X} 2$ & 1.000 & .718 \\
\hline X3 & 1.000 & .570 \\
\hline $\mathrm{X} 4$ & 1.000 & .638 \\
\hline X5 & 1.000 & .633 \\
\hline X6 & 1.000 & .691 \\
\hline$X 7$ & 1.000 & .794 \\
\hline
\end{tabular}

Extraction Method: Principal Component Analysis. Sumber : Analisis data primer, 2019

Berdasarkan dari tabel di atas dapat dijelaskan bahwa variabel X1 (manfaat) dengan nilai Communalities 0,815. ini berarti bahwa $81,5 \%$ varians dari variabel manfaat dapat dijelaskan oleh faktor yang terbentuk. Variabel X2 (kemurnian) dengan nilai Communalities 0,718 ini berarti bahwa $71,8 \%$ varians dari variabel gaya hidup dapat dijelaskan oleh faktor yang terbentuk. Variabel X3 (Rasa) dengan nilai Communalities 0,508 ini berarti bahwa 50,8\% varians dari variabel rasa dapat dijelaskan oleh faktor yang 
terbentuk. Variabel X4 (aroma) dengan nilai Communalities 0,638 ini berarti bahwa $63,8 \%$ varians dari variabel aroma dapat dijelaskan oleh faktor yang terbentuk. Variabel X5 (kemasan) dengan nilai Communalities 0,633 ini berarti bahwa 63,3\% varians dari variabel kemasan dapat dijelaskan oleh faktor yang terbentuk. Variabel X6 (kandungan gizi) dengan nilai Communalities 0,691 ini berarti bahwa $69,1 \%$ varians dari variabel kandungan gizi dapat dijelaskan oleh faktor yang terbentuk. Variabel X7 (gaya hidup) dengan nilai Communalities 0,794 ini berarti bahwa 79,4\% varians dari variabel kemurnian dapat dijelaskan oleh faktor yang terbentuk.

Hasil perhitungan dari Total Variance Explained dan Scree Plot, terlihat bahwa hanya ada dua faktor yang terbentuk dari ke tujuh variabel yang terpilih. Dalam analisis faktor variabel yang dilibatkan sering disebut dengan faktor atau disebut juga dengan component. Hasil dari analis faktor yang dilakukan, hanya terdapat dua faktor dari variabel-variabel yang dilibatkan, nilai factor loading disajikan dalam tabel berikut ini :

Tabel 7. Perhitungan Factor Loading

\begin{tabular}{lllll}
\hline & Factor loadings & \multicolumn{2}{c}{ Squared Factor loadings } \\
\hline \multicolumn{3}{c}{ Component } & \multicolumn{2}{c}{ Component } \\
\hline & 1 & 2 & 1 & 2 \\
\hline X2 & .841 & -.102 & 0.708 & 0.010 \\
X1 & .803 & -.411 & 0.646 & 0.169 \\
X4 & .793 & -.093 & 0.630 & 0.009 \\
X5 & .792 & .074 & 0.627 & 0.006 \\
X6 & .688 & .467 & 0.473 & 0.218 \\
X3 & .649 & -.386 & 0.421 & 0.149 \\
X7 & .480 & .750 & 0.231 & 0.563 \\
\hline \multicolumn{3}{c}{ Eigenvalue } & 3.734 & 1.124 \\
\hline
\end{tabular}

Sumber : Analisis Data Primer, 2019

Tabel 7 menunjukkan bahwa nilai eigenvalue untuk ke dua faktor yang terbentuk adalah 3,734 faktor I dan 1,124 untuk faktor II. Variabel X1, X2, X3, X4, X5 dan X6 masuk ke dalam faktor I. Sedangkan X7 masuk ke dalam faktor II.

\section{KESIMPULAN}

Berdasarkan hasil pengolahan data dapat disimpulkan bahwa faktor-faktor yang mempengaruhi konsumsi beras organik di Yogyakarta terdiri dari dua faktor, yaitu faktor I yang terdiri dari manfaat, kemurnian, rasa, aroma, kemasan dan kandungan gizi atau disebut sebagai faktor Produk, sedangkan faktor II yang terdiri dari variabel gaya hidup disebut sebagai sosial konsumen. Kedua faktor tersebut berpengaruh terhadap permintaan konsumen akan beras organik.

\section{SARAN}

Mengingat banyaknya manfaat dari beras organik, selain manfaat dari produk tersebut bagi kesehatan adalah manfaat terhadap keberlanjutan lingkungan, sehingga perlu disosialisasikan lebih giat lagi agar tingkat partisipasi masyarakat dalam mengkonsumsi beras organik lebih meningkat lagi.

\section{DAFTAR PUSTAKA}

Badan Pusat Statistik. 2015. Data Jumlah Rumah Tangga di Indonesia. http:// bps.go.id

Bilson Simamora, 2005. Analisis Multivariat Pemasaran. PT. Gramedia Pustaka Utama. Jakarta

Jogiyanto. 2004. Metodologi Penelitian Bisnis. BPFE. Yogyakarta.

Ni Made Tisnawati. 2015. Jurnal Piramida Vo. XI No.1;13-19.

Pradesi Sulistyana, dkk. Jurnal Agro Ekonomi Vo. 24/ No 1 Juni 2014. Yogyakarta 